\title{
Research into Corporate Shareholding Reform
}

\author{
Qing Wang
}

Jiangxi Technical College of Manufacturing, Department of Economic Management

\author{
Keywords: State Owned Enterprise; Stock System; Reform of Stock System
}

\begin{abstract}
Since the reform and opening up, some collective and private enterprises in our country have developed rapidly, and have made brilliant achievements. However, many state-owned enterprises have little effect, and the development is very difficult. This paper aims to analyze the problem from the two aspects of theory and practice, and to provide a set of system solutions for the reform of state-owned enterprises in our country. This paper first clears the concept of state-owned enterprise shareholding system reform in our country, analysis of state-owned enterprises reform struggles, the root cause of washout, put forward the problem of the shareholding system reform of state-owned enterprises and analyzes the system implementation and related measures, for our country state-owned enterprise shareholding system reform explore a road for reference.
\end{abstract}

\section{Introduction}

Shareholding system reform is a major historical problem faced by the reform of state-owned enterprises in China. How to transform the shareholding system has become one of the problems to be solved urgently for the survival and development of the state owned enterprises. Generally, reform of shareholding system reform, also known as corporations, hereinafter referred to as "restructuring", refers to the enterprise management under planned economy system, property right is fuzzy, the traditional state-owned enterprises, reform to adapt to the socialist market economy system of separating, clear property rights of modern company system enterprises. Its core is to realize the enterprise system innovation, mechanism transformation and system transformation.

The research and exploration of the shareholding system reform is the need for the liberation of the productive forces and the state-owned enterprises have made great contributions to the national economic construction. But must see soberly, with the continuous improvement of the market economy, continuous development of economy of a variety of system of ownership, the functions of the government in changing, the government should withdraw from the specific business management activities, thus creating the market environment of fair competition. The state owned capital is monopolized by many industries and fields, and the situation of government protection is gradually disappearing. The gradually deepening the reform of gradual characteristic, that shareholding reform is state-owned enterprise reform direction and goals of the scientific conclusion, favorable conditions for the joint-stock reform of the state-owned enterprises are analyzed, and put forward the general idea for the reform.

\section{Theoretical Basis for the Reform of State Owned Enterprises in China}

The state-owned enterprise is an important form of socialist public ownership, and it is an important part of the socialist economic system, and the economic basis of the socialist system. At present and in the future the joint-stock system transformation of state-owned enterprises in our country should also continue to adhere to and must adhere to the Marxist theory of property rights as a guide, closely linked to the basic national conditions of the primary stage of socialism, closely on the specific conditions of the state-owned enterprises, actively adapt to the socialism market economic development needs, will continue to make innovation in system, mechanism and management, striving to establish a standardized modern enterprise system, realize the diversification of property rights, in order to enhance the vitality and vigor of state-owned enterprises. 
The Marxist Theory of Property Right. Marx's theory of property rights is the theory of public property rights, with the West New Institutional Theory of private property rights conflict. Its basic content is:

(1) Legal relationship is a reflection of the realistic economic relations will, its content is decided by the economic relationship.

(2) Ownership is the legal form of ownership; the property right is the legal representation of production relations.

(3) The property right is not a single right but a group of rights, including ownership, possession and use rights, control rights and management rights, claim, right of inheritance and inviolability.

(4) The right of the property right can be unified, also can be separated, and there are many kinds of forms of separation.

Deng Xiaoping Theory of the Primary Stage of Socialism. (1) China is now in the primary stage of socialism and will be in the primary stage of socialism, which is the biggest reality of contemporary China. It is the overall situation of China's national conditions from the social nature and social development stage.

(2) The primary stage of socialism is not developed, including the meaning of the two level: First, our society is now a socialist society, we must stick to and cannot leave socialism; second, China's socialist society is still in primary stage, we must proceed from this reality, cannot go beyond this stage.

\section{The Urgency of the Reform of State Owned Enterprises in China}

Lack of Operational Autonomy. Enterprise is the main body of the market, the company legal person. But for a long time, the management and production of highway construction in our province take the planned economy management mode. Enterprise's human, financial, material, production, supply, sales were subject to the intervention and influence of the relevant departments, cannot be independent arrangements for their production, management and management. Enterprises have become the government's appendages, no business autonomy, difficult to operate independently, assume sole responsibility for its profits or losses, self-restraint, self-development, lost its vitality and vigor.

Enterprise Operating Efficiency is Low. In the government environment, business leaders are appointed by the competent department. He was a county magistrate yesterday, and today he is likely to be the director of the factory. Even, he was the head of the head today may become the manager. Of course, layman after long-term training and improve can be an expert, but directly to the party and government cadres and soldiers to engaged in road and Bridge Company, often because they do not understand the business, did not understand the company and blind decision-making and human, the result can only be benefit is low, it is difficult to succeed.

Integration of Government Administration with Enterprise. The economic function of the government is mainly formulation of financial policy and the development of strategic planning and arrangements for the financial revenue and expenditure, and macro regulation and control, for enterprise development and foreign investment introduction to create a good environment and, rather than the direct operation of enterprise.

\section{Key Points and Measures for the Reform of Company Stock System}

Unified Leadership, Change the Attitude of Workers. As the leader of the company, we must first take the lead to emancipate the mind, update the concept, and consciously get rid of the shackles of the administrative levels, and establish a new concept of enterprise development, do not talk about the level of. Secondly, to improve the understanding of company restructuring, enterprise restructuring is the only way which must be passed as to survive and develop in the condition of socialist market economy, is to deal with the WTO, two business opportunities. Thirdly to improve the company's restructuring and strengthening internal management, deepen the reform of organic links, to avoid three separate people, make the system interaction. 
Speed Up the Reform of Shareholding System and Clarify the Property Rights of Enterprises. According to the problem of the property right of state-owned enterprise stock system reform is not clear, the fundamental policy is to speed up the reform of stock system. Asset and capital verification and evaluation of assets, reasonably determine the asset appraisal day, engage with qualified asset appraisal firm comprehensive clearing and evaluating a company's assets, legitimate assets assessment report issued, as stated in the company's total assets, total liabilities and net assets amount. At the same time, according to relevant state policies and regulations, before the restructuring occurred 3 years should be accounts receivable and within three years indeed has formed for bad and doubtful debts of accounts receivable amount, from the state-owned net assets verification, to deal with unpaid workers to raise funds under the liability from the state-owned net assets disposal.

Reasonable Arrangement of Ownership Structure, the Implementation of the Diversification of Property Rights. Adhere to the principle of voluntary participation, equity, employee stock ownership, production technology backbone shares, management and management. Give full consideration to the operator's responsibility, the construction enterprise qualification requirements and individual workers bear ability, setting up reasonable equity structure, the scientific division of state-owned shares, employee shares ratio and employee shares in the leadership of the company ownership, middle managers' ownership, production technology backbone holding shares, employee stock ownership share. Encourage and attract social capital investment, to achieve diversification of property rights, to prevent the state-owned shares "dominance" bad phenomenon, promote the establishment of modern enterprises system.

\section{Conclusion}

Private enterprise development by leaps and bounds, has achieved remarkable results, and many state-owned enterprises have made little progress, the development is very difficult. The reason is that so far the reform of state-owned enterprises reform of the internal system, a breakthrough, the system does not touch the system itself. System, mechanism and system of "three system" is not the three level, three dimensions, three-in-one. According to the actual situation, according to the system to manage as the theme, to solve the problem of the enterprise's ability and efficiency; Mechanism to operate as the theme, to solve the problem of power and vitality of the enterprise; system to property rights as the theme, to solve the problem of corporate governance structure and the pattern of interests. Hope to help the development of the reform of state-owned enterprises.

\section{References}

[1] Mark Freeman, Robin Pearson, James Taylor. Technological change and the governance of joint-stock enterprise in the early nineteenth century: The case of coastal shipping [J]. Business History, 2007, 49(5):573-594.

[2] Garmash V M, Beloglovski S Y, Lubetsi S L. Industrial manufacturing of cerium-doped lutetium silicate crystals on enterprise joint-stock-company "north crystals" [J]. Nuclear Instruments \& Methods in Physics Research, 2002, 486(1):106-110.

[3] Wang B. Joint Stock System Reform is Foundation of Moving Toward Market of State-owned Enterprise [J]. Shanxi Coking Coal Science \& Technology, 2008.

[4] Xu Y. Primary research for safety management of joint stock system enterprise [J]. Industrial Safety \& Dust Control, 2001.

[5] He Y. The Establishment of Joint-Stock-System Enterprise Association with Capital as Tie [J]. Journal of Luoyang Technology College, 1999.

[6] Ying Y U. A new idea of joint stock system transformation for state-owned enterprise in the northeast old industrial base [J]. Journal of Changchun University, 2006. 
[7] Liang C M, Tian L X. Probe into Management of Enterprises with Joint-stock System [J]. Sci/tech Information Development \& Economy, 2001.

[8] Schwind M, Gujo O, Stockheim T. Dynamic Resource Prices in a Combinatorial Grid System[C]// null. IEEE Computer Society, 2006:49.

[9] Dong A Y. Joint-stock system-effictive choice of middl-small-sized state enterprises [J]. Journal of Shenyang Polytechnic University, 2000.

[10] Kita M. Scottish joint-stock enterprise during the Industrial Revolution [J]. Socio-economic history: shakai-keizai-shigaku, 1969, 35:262-280, 340-339.

[11]Zhao M Y. Zhang Jian's Contribution to the Practice of Joint-Stock System [J]. Journal of Nantong Teachers College, 2003.

[12]Hecker R. A System of Indices for the External Analysis of the Earning Capacity Standard and Financial Power of Industrial Joint Stock Companies [M]// Theory and Applications of Economic Indices. Physica-Verlag HD, 1978:381-387. 